\title{
Лавёрычева С.A. \\ Следственные изоляторы в системе пенитенциарных учреждений: история вопроса
}

ФКУ НИИ ФСИН России

(Россия, Москва)

doi: $10.18411 / l j-28-02-2018-18$

idsp: 000001:lj-28-02-2018-18

\section{Аннотация}

В настоящей статье кратко представлена история возникновения, изменения и становления системы учреждений и органов, обеспечивающих изоляцию от общества; определены в ней роль и место следственного изолятора.

Ключевые слова: следственный изолятор, уголовно-исполнительная системы, правовое назначение.

\section{Abstract}

This article briefly presents the history of the emergence, change and formation of the system of institutions and bodies providing isolation from society; the role and place of the detention center are defined in it.

Key words: remand prison, penal system, legal appointment.

В настоящее время правовой статус следственного изолятора (СИЗО) уголовноисполнительной системы (УИС) не имеет четкого определения. С одной стороны он предназначен для содержания под стражей подозреваемых и обвиняемых, а с другой выступает местом лишения свободы в отношении осужденных, оставленных для выполнения работ по хозяйственному обслуживанию, и срок наказания которых не превышает шести месяцев лишения свободы.

Изучение истории возникновения, изменения и становления системы учреждений и органов, обеспечивающих изоляцию от общества, позволит определить в ней роль и место следственного изолятора, а также его правовое назначение.

Анализ научной, учебной литературы и нормативно-правовых документов позволяет сделать вывод о том, что попытки формирования единой системы правоохранительных органов были предприняты еще в XVI в. Основными видами наказания в это время являлись тюремное заключение и ссылка. При этом тюремное заключение, по мнению С.И. Штамма и М.Ф. Владимирского-Буданова, «применялось не только как наказание, но и как мера предварительного заключения». На справедливость этой точки зрения указывает и одно из основных положений Соборного уложения, согласно которому допускался бессрочный срок тюремного заключения - «до выяснения обстоятельств при проведении следствия».

B XVIII веке роль тюремного заключения в качестве меры наказания снижается и к началу XIX века оно начинает применяться главным образом в отношении подследственных.

В 1873 г. был разработан проект устава о тюрьмах, в котором впервые была предпринята попытка создания единого закона, регламентировавшего деятельность тюремных учреждений Российской империи. В этом проекте большое внимание было уделено устройству тюремных зданий и условиям содержания заключенных. В связи с этим тюрьмы подразделялись на два вида: уголовные и гражданские. В свою очередь уголовные делились на предварительные, предназначенные для подследственных, подсудимых и задерживаемых полицией в административном порядке, и исполнительные - для лиц, отбывающих наказания по приговору суда. При этом предварительные учреждения подразделялись на полицейские (подстражные) и судебные (приговорные). 
Представляется, что предварительные тюремные учреждения явились прообразом следственных изоляторов, которые получили свое нормативное закрепление значительно позже.

В июле 1918 г. Временной инструкцией вводятся новые виды мест лишения свободы: 1) общие места заключения; 2) воспитательно-карательные учреждения реформатории и земледельческие колонии; 3) испытательные заведения для лиц, по отношению к которым имеются основания для послабления режима; 4) карательнолечебные для лиц с психическими отклонениями; 5) тюремные больницы.

Однако недостаточное финансирование мест заключения не позволяло ввести в действие все виды лишения свободы. В этот период фактически существовали только два вида: тюремные больницы и общие места заключения. В сложившейся ситуации последние выполняли задачи как мест предварительного заключения, так и мест исполнения уголовного наказания и пересыльных пунктов.

Однако в ноябре 1920 года принимается Положение об общих местах заключения РСФСР, которое предусматривало раздельное содержание лиц, отбывающих наказание и подследственных, которые размещались в одиночных камерах.

В указанных документах не содержалось конкретных норм, регламентирующих режим в местах заключения, а также организацию борьбы с нарушениями режима и преступностью среди заключенных. Из-за этого уровень пенитенциарной преступности стал расти.

Складывающаяся ситуация диктовала необходимость реформирования мест лишения свободы. В результате в октябре 1924 года был принят первый Исправительнотрудовой кодекс РСФСР (ИТК РСФСР), в основе которого была заложена прогрессивная система исполнения наказания в виде лишения свободы. В это время в стране уже сформировалась система органов, исполняющих наказания. Однако до 1930 г. ИТК РСФСР не предусматривал самостоятельных учреждений, предназначенных для исполнения меры пресечения в виде заключения под стражу. Эта мера пресечения в соответствии со ст. 47 ИТК РСФСР исполнялась домами заключения, в которых содержались лица, находящиеся под следствием; осужденные к лишению свободы, до вступления приговора суда в законную силу; лишенные свободы на срок до шести месяцев.

Новый Исправительно-трудовой кодекс РСФСР был утверждён 1 августа 1933 года. Он предельно упростил виды мест отбывания наказания в виде лишения свободы. Остались исправительно-трудовые колонии (фабрично-заводские, сельскохозяйственные, штрафные), учреждения для отбывания наказаний в виде лишения свободы несовершеннолетними (школы индустриального и сельскохозяйственного типа), больницы и учреждения для медицинской экспертизы, пересыльные пункты и изоляторы для подследственных. При этом в тексте ИТК РСФСР 1933 г. подчеркивалось, что они предназначены только для лиц, находящихся под следствием и судом. Оговаривалась также возможность их создания при местах лишения свободы в виде отделений.

В 1936 г. система мест лишения свободы НКВД СССР была дополнена тюрьмами, которые были предназначены для лиц, совершивших наиболее опасные преступления. В связи с этим соответствующие изменения были внесены в ИТК РСФСР, согласно которым учреждения для содержания подследственных стали называться также тюрьмами. В июне этого же года приказом НКВД СССР было утверждено Положение о следственных тюрьмах НКВД. Вплоть до начала 60-х годов тюрьмы исполняли одновременно и уголовное наказание, и меру пресечения.

Отделение мест предварительного заключения от других мест лишения свободы произошло лишь в 1963 г. приказом Министерства охраны общественного порядка РСФСР (МООП РСФСР) «О реорганизации тюрем в следственные изоляторы МООП РСФСР и изоляции лиц, осужденных к тюремному заключению». С этого момента 
следственные изоляторы являются основным местом содержания под стражей для следующей категории лиц:

a) обвиняемые, подсудимые и подозреваемые в совершении преступления, которым в качестве меры пресечения применено заключением под стражу;

б) осужденные к лишению свободы, в отношении которых приговор еще не вступил в законную силу;

в) осужденные, прибывшие из исправительно-трудовых учреждений для участия в следственных действиях;

г) транзитно-пересыльные заключенные;

д) осужденные к лишению свободы в исправительно-трудовых колониях общего режима, оставленные для работ по хозяйственному обслуживанию.

Кратко проведенный исторический анализ показал, что следственные изоляторы уголовно-исполнительной системы, предназначенные для содержания под стражей подозреваемых и обвиняемых, появились сравнительно недавно в результате продолжительных преобразований. Соответственно правовую основу их функционирования нельзя назвать совершенной. Она требует внесения изменений и дополнений в действующее законодательство.

\section{$* * *$}

1. Алексеев В.И. Среднесрочное заключение арестантов в российской и европейской тюремных системах (1879-1917 гг.) // Уголовно-исполнительная система: право, экономика, управление, 2010. - № 6. - С. 28.

2. Упоров И.В. Первое законодательное закрепление тюремного заключения как наказания в российском праве // Государство и право, 1998. - № 9. - С. 86.

\section{Наймушина Е.C. \\ Совершенствование системы взаимодействия органов и сил МЧС России и федеральных органов исполнительной власти при проведении боевых и специальных операций}

doi: $10.18411 / \mathrm{lj}-28-02-2018-19$

idsp: 000001:lj-28-02-2018-19

С каждым веком все большую остроту приобретают проблемы войны и мира. Они относятся к социально-политической сфере и заключаются в том, что из арсенала человечества в качестве средства разрешения противоречий не исключены войны. В результате эти бедствия продолжают наносить огромный урон человечеству.

Войны XX столетия сопровождались площадным поражением территорий, одномоментной массовой гибелью и санитарными потерями, как среди военнослужащих, так и среди мирного населения, разрушениями промышленных центров, хозяйственной и социальной инфраструктур в результате тотального характера применения оружия массового поражения.

За счет организованной эвакуации и стихийных беженцев ожидались перемещения огромных масс населения. И, наконец, экологические, демографические, экономические, социальные и прочие долговременные последствия войн и вооруженных конфликтов оказывались тяжелее последствий прямого применения оружия.

В третьем тысячелетии обострились и проблемы, связанные с терроризмом - в мире широкое распространение получило явление, при котором организованные сообщества и отдельные группы пытаются добиться своих социальных, политических или экономических целей путем применения угроз и насилия. Терроризм сегодня является опаснейшей разновидностью угроз обществу и приобрел черты политического 